\title{
SOLUSI KONFLIK PERAN PEREMPUAN MINANGKABAU (Kasus Perawat Yang Melanjutkan Pendidikan Ke Perguruan Tinggi)
}

\author{
Nola Mutiara Asril ${ }^{1}$, Maihasni, Alfitri ${ }^{3}$ \\ $12{ }^{3}$ Department of Sociology, Faculty of Social and Political Science, Universitas Andalas, Padang, Indonesia
}

\begin{tabular}{|c|}
\hline ARTICLE INFORMATION \\
\hline $\begin{array}{ll}\text { Submitted : } 14 \text { August } 2019 \\
\text { Review }: 03 \text { November } 2019 \\
\text { Accepted : } 22 \text { November } 2019\end{array}$ \\
\hline Available online: December 2019 \\
\hline KEYWORDS \\
\hline $\begin{array}{l}\text { Nurse; Nurse Advanced Education; Three Roles; Role } \\
\text { Conflict }\end{array}$ \\
\hline CORRESPONDENCE \\
\hline ”E-mail: ollachan3@gmail.com \\
\hline
\end{tabular}

\section{A. PENDAHULUAN}

$\mathrm{P}$ endidikan adalah bagian yang penting untuk menjaga keberlangsungan masyarakat. Sejalan dengan itu, pendidikan seperti yang dikatakan oleh Schofield yaitu memposisikan diri sebagai tempat bagi mereka untuk mengembangkan diri berdasar keunikan potensi dan kepentingannya masing-masing (Maliki, 2010). Lebih lanjut, Grene menjelaskan bahwa pendidikan adalah usaha manusia untuk menyiapkan dirinya pada suatu kehidupan yang bermakna (Martono, 2012). Dengan demikian, pendidikan dapat dirumuskan sebagai usaha yang dilakukan dengan sengaja dan sistematis untuk memotivasi, membina, mambantu, serta membimbing seseorang untuk mengembangkan segala potensinya sehingga ia mencapai kualitas diri yang lebih baik. Menurut P.A. Sorokin bahwa prestasi integritas dan pangkat berdasarkan golongan, merupakan syarat paling penting untuk mencapai posisi tertentu melalui pendidikan (Idi, 2011). Hasil dari penelitian Supriyanti ${ }^{1}$ menje-

\footnotetext{
${ }^{1}$ Supriyanti. (2015). Faktor-faktor yang Berhubungan dengan Motivasi Perawat Melanjutkan Pendidikan Tinggi Keperawatan di Rumah Sakit Islam Surakarta. Jurnal IImu Kesehatan: 1-14. from: <http://eprints.ums.ac.id/id/eprint/36077>. (diakses: 19 November 2019)
}

\section{A B S T R A C T}

This article is about nurses who continue their education to universities it required by law no. 38 of 2014 of Nursing to continue to level SI (university graduate). According to by law declared a nursing graduate Sekolah Perawat Kesehatan (SPK) who did not continue their study, will be a nursing assistant or administrative personnel. However, they do not get the task of study and only get the permission of studying and this keeps them working when they have to follow the SI education program. As a mother, worker, and student, nurses have three roles, the busy of these three roles need to be bridged to align themselves as a social being that connected to the community environment. The research question is what is the solution undertaken by students who work as nurses to save the role of the community? This article will show that Minang women who continue their education and work as nurses trying to save their role in their community at the time they are busy.

laskan ada hubungan jabatan terhadap motivasi perawat melanjutkan pendidikan tinggi keperawatan. Pendidikan memiliki peran yang besar dalam penyediaan sumber daya manusia yang berkualitas dan harus bisa menjawab tuntutan masyarakat, terutama masyarakat modern. Lamanya mengenyam pendidikan dinilai memiliki banyak memberikan pengaruh terhadap pemben tukan daya saing seseorang.

Maka inti pendidikan seiring dengan perkembangannya ialah usaha mendewasakan manusia seutuhnya lahir dan batin, baik oleh dirinya sendiri ataupun orang lain dalam arti tuntutan supaya anak didik memiliki kemerdekaan berfikir, merasa, berbicara, dan bertindak serta percaya diri dengan penuh rasa tanggung jawab dalam setiap tindakan dan perilaku sehari-hari (Tatang, 2012).

Semakin tinggi tingkat pendidikan, semakin tinggi peluang seseorang untuk meningkatkan kualitas daya saing mereka, dan semakin rendah tingkat pendidikan akan semakin sulit menumbuhkan kemampuan dan daya saing seseorang (Maliki, 2010). Hal ini berkaitan sebagaimana pendidikan selalu mengambil format tertentu, karena ketika sejarah berubah, pendidikan pun 
berubah. Sehubungan dengan itu, pendidikan keperawatan khususnya mengalami berbagai dinamika perkembangan pendidikan. Di Indonesia pendidikan keperawatan masih merupakan pendidikan yang bersifat vocational, yaitu pendidikan keterampilan, sedangkan idealnya pendidikan keperawatan itu harus bersifat profesionalisme. Maka, salah satu langkah meningkatkan kualitas pelayanan kesehatan rumah sakit adalah dengan meningkatkan kualitas Sumber Daya Manusia perawat melalui peningkatan pendidikan formal peraw. ${ }^{2}$ Jika praktik keperawatan dilihat sebagai praktik profesional maka harus ada otoritas atau kewenangan.

Jenis perawat berdasarkan Undang-Undang Nomor 38 Tahun 2014 tentang Keperawatan adalah perawat vokasi dan perawat profesi. Dalam penelitian ini perawat yang melanjutkan pendidikan ke perguruan tinggi merujuk pada perawat yang belum memiliki pendidikan minimal diploma III, namun mempunyai kompetensi sebagai tenaga kesehatan yang diperoleh melalui pengalaman kerja di lapangan.

Selanjutnya, di dalam Undang-Undang tersebut lebih menjelaskan batasan kewenangan profesi perawat terkait pendidikan. Apabila dalam 6 tahun sejak diundangkan tenaga kesehatan tidak memiliki kualifikasi minimal Diploma III maka bagi tenaga kesehatan dapat menimbulkan beberapa dampak. Adapun dampak yang ditimbulkan adalah menjadi asisten tenaga kesehatan, tidak memiliki kewenangan dalam melaksanakan praktik sebagai tenaga kesehatan, dan harus bekerja di bawah supervise tenaga kesehatan. Namun, dibalik pendidikan dan karir yang berhubungan erat, Undang-undang No. 38 tahun 2014 tentang Keperawatan menjadi sebuah tantangan bagi perawat. Pertama, perawat yang melanjutkan pendidikan SI telah berusia 40 tahun, dalam hal ini mereka membutuhkan konsentrasi dan memaksimalkan kemampuan untuk berfikir dan belajar. Kedua, mereka sudah menikah dan memiliki anak. Hal ini membuat konsentrasi menjalani pendidikan akan terbagi dengan berbagai urusan keluarga. Selain itu, mahasiswa yang sudah menikah dapat mengalami penurunan dalam hal keaktifan kuliah karena dampak dari pernikahan kuliah akan terbengkalai dan tanggungjawab akan bertambah (Aryati, Prastiwi, \& Rosdiana, 2017). Ketiga, peran mereka sebagai pekerja dengan segala tugas-tugasnya sebagai perawat di rumah sakit. Kehidupan sehari-hari wanita berada dalam suatu konteks beban ganda. Peran-peran tersebut sama-sama membutuhkan waktu tenaga, perhatian, sehingga kalau peran yang

\footnotetext{
${ }^{2}$ Setyaningsih, A., Wuryanto, E., \& Sayono. (2013). Faktor-Faktor yang Berhubungan dengan Motivasi Perawat Melanjutkan Pendidikan ke Jenjang S1 Keperawatan di Rumah Sakit Roemani Muhammadiyah Semarang Tahun 2012. FlKkes Jurnal Keperawatan , Vol.6, No.2, pp.119-138.From:<https://jurnal.unimus.ac.id>.(diakses: 05 April 2018)
}

satu dilakukan dengan baik, dan yang lain terabaikan maka akan menimbulkan konflik peran (Saputri, 2016). Dengan kata lain, konflik dapat terjadi apabila individu dituntut untuk memerankan berbagai peran, seperti pekerja, rekan kerja, pasangan hidup, peran sebagai orang tua dan peran sebagai anggota masyarakat.

Pendapat saya di sini adalah melanjutkan pendidikan izin belajar, melaksanakan peran sebagai ibu, dan sebagai pekerja harus bisa bijaksana membagi waktu, tanpa mengabaikan naluri untuk saling tolong menolong, setia kawan, toleransi serta simpati dan empati terhadap sesama. Adanya keinginan untuk dapat memenuhi tuntutan peran dalam kehidupan berkeluarga dan pekerjaan yang tidak jarang dapat menimbulkan konflik dikarenakan ketidakmampuan seseorang dalam hal membagi waktu dan komitmen untuk peran pekerjaan dan keluarga. ${ }^{3}$ Maka, pentingnya solusi peran agar membuat dirinya tetap terlibat dalam komunitas tanpa meninggalkan tugas dan tanggungjawab ke tiga peran yang lain.

Oleh karena itu, artikel ini bertujuan untuk mengetahui solusi yang mereka lakukan untuk memainkan peranan itu secara baik. Sedangkan manfaat penelitian ini secara teoritis (akademis) berkontribusi bagi mahasiswa dalam melengkapi kajian yang mengarah kepada pengembangan ilmu pengetahuan yang berhubungan dengan budaya Minang. Serta secara praktis hasil kajian ini dapat memberikan masukan bagi pengambil kebijakan sehingga dapat mempertimbangkan nilai-nilai, budaya serta kecendrungan yang ada di masyarakat.

\section{B. METODE}

$\mathrm{P}$ enelitian ini dilaksanakan selama 9 bulan yaitu dari Bulan November 2017 sampai Bulan Juli 2018. Lokasi Penilitian ini di Stikes Syedza Saintika Padang, dimana lokasi. tersebut adalah tempat informan melaksanakan pendidikan. Penelitian ini menggunakan data primer dan sekunder. Pengumpulan data primer menggunakan pedoman wawancara kepada para informan dan data sekunder diperoleh dari instansi-instansi terkait. Penelitian ini telah dipelajari dengan menggunakan metode penelitian kualitatif sesuai dengan model Miles dan Huberman untuk menjelaskan realitas dan interpretasi-interpretasi individu berkaitan dengan perbuatan-perbuatan yang dilakukan dengan menggunakan teori peran Stryker yang menghu-

\footnotetext{
3 Susanti, S., \& Ekayati, I. N. (2013). Peran Pekerjaan, Peran Keluarga, dan Konflik Pekerjaan Pada Perawat Wanita. Persona, Jurnal Psikologi Indonesia, Vol. 2, No. 2, pp. 183-190. Doi: https://doi.org/10.30996/persona.v2i2.118
} 
bungkan orientasinya dengan interaksionisme simbolik Meadian. Berdasarkan teori ini, meskipun berawal dari Mead namun bergerak melampui Mead untuk memperkenalkan prinsip dan konsep teori peran serta menerangkan pengaruh timbal balik antara aktor dan struktur sosial. Menggunakan teori peran dari Stryker ini dapat mengeksplorasi kehidupan individuindividu sebagai makhluk sosial yang terlibat dalam ke tiga peran, karena menurut Stryker harus ada yang menjembatani struktur sosial dan individu.

\section{HASIL DAN PEMBAHASAN}

$\mathrm{B}$ ahwa untuk menyelaraskan manusia sebagai makhluk ekonomi dan sosial mereka melakukan refleksi, dan dalam melakukan persepsi yang kritis mereka menyadari keterbatasannya sebagai manusia yang tidak bisa hidup sendiri. Menurut Freire, manusia dapat mengatasi dimensi tunggal, serta manusia mampu menjangkau hari kemarin, mengenal hari ini, dan menemukan hari esok. Maka para aktor sosial perlu memahami dirinya sebagai subjek dan juga sebagai objek supaya dapat mengatasi keterbatasan interaksi mereka dengan masyarakat akibat dari tiga peran yang dijalankan melalui solusi konflik peran yang dapat dijelaskan sebagai berikut:

\section{Menitipkan Hadiah Untuk Acara \\ Pernikahan}

Menitipkan hadiah untuk acara pernikahan adalah cara yang dilakukan ketika mereka tidak bisa memenuhi undangan pernikahan dari teman atau kolega karena ada peran lain yang perlu diprioritaskan untuk dilaksanakan. Diantara ke tiga peran yang dimiliki, yaitu sebagai mahasiswa, pekerja dan sebagai ibu, biasanya adalah peran sebagai mahasiswa yang menjadi hambatan untuk hadir dalam acara pernikahan di lingkungan sosialnya. Oleh karena itu, dengan menitipkan hadiah diharapkan bisa mengganti kehadirannya untuk datang ke pesta pernikahan tersebut.

Uang atau hadiah yang diberikan pada prakteknya harus dikembalikan serupa atau sama ketika mereka juga mengadakan pesta pernikahan, ini menjadi transaksional karena ketika ada halangan yang membuat mereka untuk tidak hadir dalam acara pesta pernikahan tersebut, maka ada pelunas atau orang suruhan untuk menitipkan uang atau hadiah yang diberikan. ${ }^{4}$ Tindakan ini menjelaskan bahwa

\footnotetext{
${ }^{4}$ Zainy, M. Q. (2008). Pandangan Masyarakat Terhadap Tradisi Pesta Perkawinan (Kasus di Pesisir Desa Kilensari, Kec. Panarukan, Kab. Situbondo). Malang: Universitas Islam Negeri Malang. From: <https://docplayer.info/46808541-Pandangan-masyarakat-terhadaptradisi-pesta-perkawinan-kasus-di-pesisir-desa-kilensari-kecpanarukan-kab-situbondo.html>. (diakses 06 Desember 2018).
}

peran mengandaikan seperangkat harapan. Jadi, uang dalam bentuk amplop atau kado menawarkan diri menjadi sarana untuk menga tasi jarak. Dengan demikian uang memiliki fungsi yang unik, menciptakan jarak antara orang dengan objek, kemudian menjadi sarana untuk mengatasi jarak tersebut.

Sehingga, amplop atau kado menjadi sarana dan simbol sebagai perwakilan dirinya agar orang tersebut terhitung hadir atau datang dalam acara pesta pernikahan itu. Tindakan atau perilaku yang dimunculkan ini sangat menen tukan keramahan lingkungan terhadap kehidupan nya sendiri. Mereka yang pada saat itu lebih memprioritaskan peran sebagai mahasiswa untuk dilaksanakan, lebih memilih mengganti kedatangannya melalui amplop atau kado. Ini adalah cara bagaimana mereka memelihara lingkungan dengan mensikapi kenyataan akan perannya.

Selain itu sifat dasar masyarakat Minang ada rasa setia kawan (solidaritas) yang tinggi dan rasa kebersamaan (Amir, 2011). Maka untuk menjaga hal itu, meskipun mereka tidak datang, hadiah atau amplop tetap jalan. Menurut Mauss sendiri, dalam hubungan atau bergaul dengan orang lain, menolak untuk memberi hadiah, ataupun lalai mengundang adalah sama dengan menolak untuk menerima, sama dengan suatu penolakan terhadap saling berhubungan dan persahabatan. Karena seseorang memberi sesuatu atau hadiah pada orang lain karena ia didorong untuk melakukan hal itu, penerima atau yang mengundang mempunyai semacam hak pemilikan atas segala sesuatu yang menjadi milik dari si pemberi. Hak ini dinyatakan dan dibayangkan sebagai semacam ikatan sosial. Oleh karena itu, apa yang dilakukan oleh individu-individu yang terlibat kesibukan adalah cara yang ia pikir telah melaksanakan harapan orang lain dan mengharapkan orang lain bertindak dengan cara-cara tertentu pula.

Jika merujuk dari penjelasan Simmel mengenai dasar kehidupan sosial, adalah individu atau kelompok individu yang sadar dan berinteraksi satu sama lain untuk beragam motif, tujuan, dan kepentingan. Ada kreativitas terhadap bentuk interaksi, kemampuan aktor untuk menciptakan struktur sosial. Dengan kata lain, aktor dapat mengambil dorongan eksternal, menjajakinya, mencoba hal atau tindakan yang berbeda, kemudian memutuskan apa yang sebaiknya dilakukan.

Seperti yang disampaikan oleh Stryker dalam membangun orientasinya bahwa aktor tidak semata menerima peran, namun mereka berpikiran aktif dan kreatif terhadap peran mereka. Ada cara pandang kultural yang berusaha untuk memahami berbagai praktik sosial Minangkabau tersebut "dari dalam" kelompok sosialnya yang elemen-elemenya (manu-sia) diasumsikan memiliki kemampuan 
dan kebebasan bertindak aktif dan kreatif, kemudian cara pandang struktural yang menempatkan elemen-elemen struktur, yaitu manusia seolah tidak memiliki pilihan lain selain tunduk pada hukum keseluruhan. ${ }^{5}$ Apa yang dilakukan oleh individu-individu, tidak hanya begitu saja menerima peran. Ketika peran-peran itu datang secara bersamaan ia memikirkan apa yang harus dilakukan diantaranya, dan apa yang perlu mereka perbuat untuk menjembatani peranperan tersebut, hal ini mengindikasikan mereka aktif dan kreatif. Teori peran Stryker mengkombinasikan konsep peran (dari teori peran) dan konsep diri (dari teori interaksionisme simbolik).

Jadi, konsep peran dan konsep diri dalam menitipkan hadiah untuk acara pernikahan tidak dilakukan secara terpisah. Perilaku tersebut dipengaruhi oleh harapan peran dan identitas diri, lalu mereka sebagai aktor memahami dirinya sebagai subyek dan sebagai obyek sehingga mereka memiliki kemampuan kritis untuk membuat pilihan dan mengubahnya untuk mangatasi keterbatasan dalam pelaksanaan peran. Hampir semua yang dilakukan adalah hasil dari memilih tindakan dengan suatu cara tertentu bukan cara yang lain. Keputusan untuk melakukan peran tertentu tersebut dapat mengatasi konflik peran sesuai dengan situasi dimana mereka menemukan diri mereka dan mewujudkan tindakan sesuai dengan situasi sosial dimana mereka tinggal.

\section{Menyesuaikan Waktu Pergi Ta'ziah}

Konflik peran timbul dari tugas-tugas yang bertentangan dalam satu peran tunggal atau dari tuntutan yang bertentangan terhadap berbagai peran yang berbeda. Sehingga menyesuaikan waktu merupakan cara yang dilakukan oleh individu-individu untuk melaksanakan peran yang lain ditengah kesibukan yang dijalani. Pergi ta'ziah merupakan kewajiban bagi setiap muslim untuk datang ke rumah duka. Ini merupakan peran sebagai warga atau individu yang berada di lingkungan tempat tinggal yang sama atau jauh dari lingkungan tempat tinggal, dan merupakan sebagai wujud memiliki sikap dan perasaan mengenai perilaku peran ketika mendengar kabar duka, dan ini juga merupakan kemampuan untuk menempatkan diri pada situasi atau kondisi yang dihadapi oleh orang lain.

Menyesuaikan waktu pergi ta'ziah disebut sebagai solusi yang mereka lakukan untuk memainkan peranan itu secara baik karena individu-individu mencari jalan keluar dari kesibukannya untuk tetap datang tanpa

\footnotetext{
${ }^{5}$ Arifin, Zainal. (2009). Dualitas Praktik Perkawinan Minangkabau. Jurnal Humaniora, Volume 21, No.2, p.151. doi: https://doi.org/10.22146/jh.963.
}

melibatkan orang lain untuk mewakili dirinya di tengah lingkungan. Hal ini sebagaimana konflik peran dapat dikendalikan oleh rasionalisasi, pengkotakan, dan ajudikasi. Jadi, bagi mereka yang menyesuaikan waktu pergi ta'ziah tanpa digantikan oleh orang lain adalah kesadaran tentang status dan posisi dirinya sebagai makhluk sosial, yang merasa memiliki tanggung jawab dan kewajiban di dalam kebersamaan. Etika menjadi salah satu sifat yang harus dimiliki oleh setiap individu Minang.

Mereka yang pergi ta'ziah dilakukan sebelum atau sesudah menyelesaikan tugas atau peran lain dan ini merupakan penunjukan ke diri sendiri menjadi bagian dari harapan diri yang diinternalisasikan dengan perilaku mereka sendiri. Jika menyesuaikan waktu pergi ta'ziah dihubungkan dengan teori peran Stryker dalam menjelaskan solusi agar memainkan peranan secara baik, salah satu prinsip umum Stryker menjelaskan bahwa ketika berinteraksi, manusia mendefenisikan situasi dengan mengaplikasikan nama-nama terhadapnya, terhadap peserta, terhadap diri mereka sendiri dan terhadap ciri-ciri khusus dari situasi. Penetapan situasi ini kemudian digunakan oleh aktor untuk mengorganisir perilaku mereka. Jadi, menyesuaikan waktu dengan jadwal tugas-tugas mereka untuk bisa datang ke rumah duka adalah mendudukkan individu sebagai pihak yang aktif dalam menetapkan perilakunya serta membangun harapan-harapan sosial. Karena memperlihatkan emosi tidak hanya semata-mata hasil biologi, namun seperti halnya pikiran adalah hasil berpikir, tergantung sosialisasi (Henslin, 2006). Oleh karena itu, menyesuaikan waktu dengan kehadiran adalah hasil berpikir, ada perasaan emosional yang ingin diungkapkan kepada orang lain dan mendapat tanggapan emosional dari orang lain pula. Jika seandainya mereka tidak hadir ada perasaan malu atau segan ketika bertemu dengan salah satu anggota keluarga yang mendapat musibah.

Ada ungkapan falsafah minang 'kaba baiak baimbauan kaba buruak bahambauan' - Jika merayakan suatu hal yang membahagiakan maka hendaklah mengundang tetangga dan handai tolan, tetapi apabila terjadi musibah atau kabar buruk pada anggota masyarakat, orang lain akan berdatangan secara spontan, tanpa dihimbau penduduk segera berdatangan, dan tanpa diminta akan memberikan bantuan, dan ini masih di anut oleh mereka dalam menjalankan kehidupan sosial. Dengan demikian, pengaruh timbal balik antara aktor dan struktur sosial dijembatani atau masih difasilitasi oleh sistem tradisional, mereka tidak dipengaruhi oleh caracara modern, jadi menyesuaikan waktu adalah solusi dalam memainkan peranan yang timbul dari proses berpikir terhadap defenisi situasi yang dianut oleh masyarakat sekitar. Struktur sosial disini membantu membatasi hingga 
ditingkat mana peran boleh 'diciptakan' ketimbang hanya 'diterima'.

\section{Hadir Sebentar Membantu Memasak dalam Sebuah 'Alek'}

Keputusan perempuan yang memilih untuk menjalani sebuah pekerjaan, terutama bagi perempuan yang telah menikah, disebut bahwa ia memiliki peran ganda. Peran ganda ini juga dijelaskan dalam penelitian yang dilakukan oleh Meliza bahwa dalam keseharian, perempuan memiliki peranan penting. Perempuan sangat dibutuhkan hampir disetiap aspek kehidupan yaitu di dalam keluarga menjadi ibu dan istri sedangkan di luar lingkungan itu perempuan juga bekerja ${ }^{6}$ Tugas perempuan pekeraja menjadi lebih banyak, disamping tuntutan untuk memenuhi kewajibannya di dalam rumah tangga, ia juga memiliki beban untuk menyelesaikan tugas dan tanggungjawab di dalam pekerjaan. ${ }^{7}$ Namun, sebagai makhluk sosial, seseorang perlu untuk ikut menjadi bagian dalam kegiatankegiatan yang diadakan di lingkungan, hubungan interaksi yang terus berjalan dan saling membantu dapat menumbuhkan ikatan yang baik dengan anggota masyarakat yang lain.

Oleh karena itu, pada sub bab ini merupakan gambaran mengenai solidaritas sosial yang merupakan perasaan atau ungkapan dalam sebuah kelompok yang dibentuk dari kepentingan bersama. Eksistensi keteraturan sosial dalam masyarakat disebut solidaritas sosial yang dimantapkan oleh sosialisasi, dan melalui proses tersebut manusia secara kolektif belajar standarstandar atau aturan perilaku (Jones, 2009). Seperti tindakan yang ditunjukkan oleh mereka saat datang membantu memasak dalam sebuah alek. Ini adalah kegiatan yang masih dilakukan oleh ibu-ibu yang tinggal di lingkungan perumahan perkotaan, biasanya orang-orang yang ikut membantu adalah dari pihak keluarga dan para tetangga, tidak terkecuali bagi wanita yang bekerja.

Hal ini menunjukkan kerjasama perempuan Minang masih dijaga dengan baik. Karena seseorang dianggap ada, bila ia berhasil menjadi sosok yang diperlukan di kaumnya dan menjadi bagian yang tidak terpisahkan dari kelompoknya. Jadi, peran ini dipengaruhi oleh keadaan sosial yang datang dari lingkungan tetangga. Oleh karena itu, bagi mereka yang memiliki pekerjaan sambil kuliah, tentunya kegiatan ini tidak bisa ia lakukan secara penuh, sehingga mereka yang bekerja dan kuliah hanya bisa hadir sebentar untuk membantu memasak dalam sebuah alek pada malam hari.

\footnotetext{
${ }^{6}$ Meliza, R., Iskandar, B. S., \& Soemarwoto, R. S. (Juni 2019). Aspek Ekonomi Pada Kehidupan Perempuan Lanjut Usia: Studi Etnografi di desa Demuk, Kecamatan Pucanglaban, Kabupaten Tulungagung. Jurnal Antropologi: Isu-Isu Sosial Budaya-vol.21.No.01, 11-21. doi:https://doi.org/10.25077/jantro.v21.n1.p11-21.2019

${ }^{7}$ Ermawati, S. (2016). Peran Ganda Wanita Karier (Konflik Peran Ganda Wanita Karier Ditinjau dalam Perspektif Islam). Jurnal Edutama , Vol. 2, No. 2, pp. 59-69.doi: http://dx.doi.org/10.30734/jpe.v2i2.24
}

Singkatnya, ada nilai-nilai sosial yang diciptakan dari kebersamaan dalam kegitan memasak itu. Selain membuat kondisi sosial menjadi akrab, menyempatkan hadir ditengah kesibukan dapat menciptakan tanggapan positif dari tetangga atau lingkungan. Meski masyarakat semakin modern dan spesialisasi setiap orang berbeda dalam setiap bidang pekerjaan dan peranan sosial. Namun tetap saja solidaritas sosial harus tetap terjaga untuk menciptakan keteraturan dalam kehidupan bermasyarakat dan menghindari ketidakharmonisan dalam pergaulan.

Berdasarkan situasi tersebut, membantu memasak dalam sebuah alek merupakan suatu bentuk solidaritas atau bentuk kerjasama dan kepedulian ibu-ibu yang tinggal di lingkungan perumahan perkotaan. Bahkan jika di telusuri, hadir walaupun sebentar mencerminkan harapan akan dibalas dengan cara yang sama, jika sewaktu-waktu mereka juga mengadakan pesta pernikahan.

Seperti yang dijelaskan oleh Stryker dalam salah satu prinsip umum yang dibangunnya bahwa ketika berinteraksi, manusia mendefenisikan situasi dengan mengaplikasikan namanama terhadapnya, terhadap peserta, terhadap diri mereka sendiri dan terhadap ciri-ciri khusus dari situasi. Maka, hadir sebentar membantu memasak dalam sebuah alek adalah bagian dari bagaimana para aktor mengorganisir perilaku mereka setelah melakukan penetapan situasi. Hal ini dikarenakan individu sebagai aktor memiliki konsep peran dan konsep diri yang tidak dapat dipisahkan. Jika ke dua hal ini digabungkan maka akan terjadi pengaruh timbal balik. Mereka dapat memahami dirinya sebagai subyek dan juga sebagai obyek, maupun sebagai entitas individual, sehingga memberikan kesadaran tentang status dan posisi dirinya adalah kehidupan bersama, serta bagaimana tanggung jawab dan kewajiban di dalam kebersamaan. Bersamaan dengan itu mereka mempunyai kesadaran bahwa jika tidak ikut serta dalam kegiatan tersebut, tingkat dimana mereka bisa memanfaatkan lingkungan saat berada pada situasi yang sama akan rendah. Jadi, mereka yang disibukkan oleh aktivitas pekerjaan dan pendidikan mengkondisikan peran-peran tersebut sehingga dapat hadir sebentar di malam hari. Dengan demikian, meskipun peran mereka sebagai mahasiswa, ibu, dan sekaligus pekerja dapat memberikan batasan-batasan, tetap saja manusia adalah makhluk yang mampu menciptakan.

\section{Melibatkan Tetangga Dalam Acara Syukuran}

Gambaran mengenai peran perempuan Minang dijelaskan dalam sebuah literatur Zainal Arifin (2013) tentang Bundo kanduang yang "diminta" untuk mengurusi urusan rumah tangga 
saja, menangani persoalan rumah tangga, seperti perkawinan, masak memasak, atau perhiasan rumah, yang dari pemaparan tersebut merupakan dasar mengenai perempuan yang diasumsikan "pantas" hanya memiliki peran domestik, ini disadari atau tidak sudah melegitimasi dalam diri perempuan meski mereka telah bergabung dalam aktivitas pada sektor publik di berbagai bidang, sehingga dapat menghasilkan konflik peran. ${ }^{8}$ Dalam hal yang terjadi di lapangan, kehidupan sosial sangat erat kaitannya dengan bagaimana bentuk kehidupan itu berjalan. Prakteknya, seperti melaksanakan acara syukuran yang biasa dilakukan di lingkungan tempat tinggal jika ada anggota dalam keluarga melaksanakan pernikahan, khitanan, aqiqah, kematian, pindah rumah, serta berangkat untuk perjalanan panjang seperti pergi umroh atau naik Haji, dimana acara dimulai dengan doa bersama yang kemudian diteruskan dengan makan-makan bersama dengan tujuan mendapat keselamatan dan perlindungan dari Allah S.W.T. Tentunya apa yang dikerjakan ini membutuhkan bantuan dari orang lain. Bagi individu-individu yang terlibat kesibukan dalam pelaksanaan peran sebagai mahasiswa, pekerja dan sekaligus ibu akan merasa kesulitan jika mereka meng-cover seluruh aktivitas tersebut sendirian.

Manusia sebagai makhluk sosial membutuhkan kehadiran orang lain dalam kehidupannya, karena dalam pemenuhan kebutuhan baik hal tersebut berupa kebutuhan fisik, kebutuhan sosial, dan kebutuhan psikis memerlukan bantuan orang lain, karena tidak mungkin bagi manusia untuk memenuhi atau melakukannya sendiri, dan jika individu mengalami tekanan yang dirasa cukup berat baginya dan merasa kurang mampu untuk memecahkan sendiri atau tidak sanggup mengcover tugas-tugasnya, maka ia akan meminta bantuan pada orang lain yang ia percaya dapat memecahkan persoalan atau permasalahan yang dihadapi. Jika tidak demikian tentu akan menimbulkan masalah, karena melibatkan orangorang yang akan membantu adalah suatu bentuk kesadaran terhadap diri dan situasi apabila terjadi suatu keadaan atau peristiwa yang dipandang dapat menimbulkan masalah.

Kehidupan sosial terkait dengan interaksiinteraksi antara individu satu dengan individu lainnya, dan proses interaksi sosial juga dapat berupa bentuk kerjasama yang menghasilkan keserasian sosial, tercipta suasana hubungan yang dinamis, seimbang, dan serasi diantara pelbagai individu dan kelompok. ${ }^{9}$ Dengan kata

\footnotetext{
${ }^{8}$ Arifin, Zainal. (2013). Bundo Kanduang: (hanya) Pemimpin di Rumah (Gadang). Jurnal Antropologi Indonesia , Vol.34 No.2, pp. 124-133. Doi:https://doi/org/10.7454/ai.v34i2.3968

9 Shonhaji. (2017). Keterlibatan Perempuan dalam Mewujudkan Keserasian Sosial Pada Masyarakat Multietnik di Lampung. Jurnal TAPIs, Vol. 14, No. 01, pp. 18-44.

Doi:https://doi.org/10.24042/tps.v13i1.1397
}

lain, manusia sebagai makhluk sosial membutuhkan manusia lain untuk hidup bersama dan bekerjasama. Maka, melibatkan tetangga dalam acara syukuran merupakan solusi peran yang dilakukan oleh para ibu yang bekerja dan sibuk kuliah, karena mereka berada pada situasi dimana mereka membutuhkan bantuan orang lain. Melibatkan tetangga dalam acara syukuran dan menerima bantuan juga manifestasi dari bagaimana mereka melibatkan diri dalam lingkungan. Intinya, acara melaksanakan syukuran terkait dengan posisi mereka dalam keluarga. Individu-individu yang melaksanakan tiga peranan akan merasakan kesulitan jika mereka yang meng-cover seluruh aktivitas itu sendirian. Menyadari hal itu seminggu sebelum acara mereka sudah memberitahu para tetangga bahwa mereka akan melaksanakan acara syukuran. Selain itu juga ada diantara individuindividu yang menjadi pihak melaksanakan syukuran mengkikuti perubahan tren yang ada, misalnya memakai jasa catering. Namun ketika porsi makanan dari pihak catering mulai tidak mencukupi untuk tamu sedangkan acara masih belum selesai, para tetangga akan segera mengcovernya. Saling meng-cover ini tentu saja dapat meringankan kesibukan mereka yang terlibat dalam ketiga peran.

Kriteria ini juga dianggap ideal untuk menjadi sifat-sifat orang-orang Minang, solidaritas yang tinggi, rasa kebersamaan, dan rasa tolong menolong (Amir, 2011). Hal ini nampak jelas bahwa setiap manusia meskipun mempunyai kedudukan dan kekayaan, mereka selalu membutuhkan manusia lain, tidak pernah ada manusia yang mampu menjalani kehidupan tanpa bantuan orang lain.

Teori peran dari Stryker dapat menjelaskan bagaimana individu melibatkan tetangga dalam acara syukuran sebagai solusi untuk memainkan peranan dalam menjalankan kehidupan. Stryker mengkombinasikan konsep peran (dari teori peran) dan konsep diri (dari teori interaksionisme simbolik). Bagi setiap peran orang lain, setiap individu mempunyai, ditampilkan dalam berinteraksi dengan defenisi tentang dirinya yang berbeda dari orang lain yang dinamakan identitas. Jadi, perilaku dalam suatu bentuk interaksi dipengaruhi oleh harapan peran dan identitas diri.

Individu-individu yang terlibat dalam tiga peran, yaitu ibu, pekerja dan mahasiswa sadar bahwa ia tidak bisa melaksanakan pekerjaan itu dengan dirinya sendiri tanpa bantuan dari orang lain. Jadi mereka mulai mempelajari bagaimana menggolongkan dan mengklasifikasikan maupun bagaimana mereka diharapkan bertindak terhadap permasalahan itu. Dari tahap ini individu harus mampu bergerak dari tingkat aktor ke tingkat struktur sosial, lalu kembali lagi ketingkat aktor, dimana mereka mampu menciptakan. Artinya, teori interaksionisme simbolik dan 
identitas mendudukkan individu sebagai pihak yang aktif dalam menetapkan perilakunya.

Tujuan mengintegrasikan interaksionisme simbolik yang dikemukakan oleh Stryker bahwa harus ada sebuah kerangka konseptual yang memfasilitasi gerakan ini. Dari hasil penelitian, gerakan melintasi ini difasilitasi oleh sistem tradisional yang masih digunakan oleh individu sebagai aktor untuk menyelamatkan perannya.

\section{Melibatkan Anak dalam Kegiatan Arisan}

Konflik peran terjadi ketika individu-individu yang diharapkan melakukan beberapa peran sekaligus dapat membawanya pada pertentangan peran. Kasus perawat yang melanjutkan pendidikan ke perguruan tinggi ini melibatkan peran-peran yang dilakukan dalam aktifitas harian. Dengan kata lain, ketika individu menyetujui sebuah peran maka mereka sekaligus memikul beban. Hampir semua orang mengikuti panduan mengenai hal-hal yang 'pantas' bagi suatu peran. Sehingga orang biasanya ingin melakukan apa yang menurut peran itu pantas (Henslin, 2006). Maka, peranperan yang telah disusun oleh masyarakat mengatur apa dan bagaimana peran setiap orang dalam pergaulannya. Apabila semua orang patuh terhadap persyaratan peran, dimana di dalamnya ada serangkaian hak, kewajiban, harapan, dan norma serta perilaku seseorang yang harus dihadapi dan dipenuhi, maka kehidupan sosialnya akan tetap harmonis. Namun, jika menyalahi persyaratan peran tentu akan menjadi konflik peran dan ini akan mempengaruhi serta mengganggu hubungan sosial antar manusia dalam kehidupan sehari-hari. Peran sangat efektif dalam mengerangkeng orang. Oleh karena itu adakalanya seorang individu tidak mampu untuk menjalankan peran yang melekat terhadap dirinya dan ini dapat mengganggu kehidupan sosial individu.

Melibatkan anak dalam kegiatan arisan merupakan salah satu solusi bagi perempuan yang terlibat dalam aktivitas yang dilakukan untuk memainkan peranan secara baik. Individu memegang sejumlah peran yang berbeda dan dituntut untuk melakukan banyak hal tetapi tidak tersedia waktu untuk menyelesaikannya. Maka untuk mengatasi keterbatasan terhadap pelaksanaan peran lain akibat dari tiga peran yang dijalankannya. Anak dalam hal ini adalah sebagai penyelamat peran bagi mereka yang terkerangkeng oleh ke tiga peran yaitu sebagai mahasiswa, pekerja dan sebagai ibu.

Berdasarkan penjelasan di atas, melibatkan anak dalam kegiatan arisan adalah sebagai ganti ketidak ikutsertaan, dan ini dirasakan pantas oleh mereka menurut situasi dirinya dengan situasi dan kondisi di lingkungan. Oleh karena itu, solusi untuk memainkan peranan yang dilakukan ini adalah cara bagaimana peran mereka dengan kelompok-kelompok tertentu di lingkungan dapat bergerak tanpa kehadiran dirinya.

Solusi ini menunjukkan sifat pribadi orang Minang, yaitu dengan berpikir jauh kedepan, maka akan dapat meramalkan apa yang akan terjadi sehingga tetap selalu waspada (Amir, 2011). Melibatkan anak juga bisa untuk mengantisipasi keuntungan atau kerugian yang dicapai dari tujuan kegiatan arisan itu. Jadi, ketika dalam pengundian atau "kocok arisan" ada yang tidak hadir, dan nama yang tidak hadir itu keluar maka dinyatakan "hangus". Untuk itu dengan melibatkan anak, mereka mengantisipasi situasi demikian. Berdasarkan hal tersebut, mengganti ketidakikutsertaan dalam kegiatan arisan yang terjadi di lingkungan tempat tinggal dengan cara melibatkan anak merupakan sebuah solusi untuk menjalankan kehidupan sosialnya.

Jika solusi peran ini dikaitkan dengan teori peran stryker dengan melibatkan anak dalam kegiatan arisan maka ini sudah menjadi role making dimana individu sebagai aktor bisa menciptakan kreativitas dan membentuk interaksi. Dengan demikian, jalan mereka untuk tetap terlibat dengan masyarakat tetap menggunakan sistem tradisional yaitu dengan melibatkan anak mereka agar dirinya tetap terhitung dalam interaksi.

\section{KESIMPULAN}

$\mathrm{M}$ elalui hasil penelitian terhadap perawat yang terlibat konflik peran saat melanjutkan studi SI, dapatlah dipahami bahwa konflik peran ini adalah suatu keadaan dimana peran-peran menjadi dilematis, di satu sisi mereka sebagai bawahan harus patuh terhadap perintah pimpinan, di sisi lain mereka harus patuh terhadap perannya sebagai mahasiswa. Dalam konteks ini, memberikan penekanan bahwa struktur sosial dianggap 'kerangka', dimana struktur sosial memiliki wilayah kotak-kotak kehidupan, seperti keluarga, pekerjaan, pendidikan dan masing-masing kotak itu berisi stratifikasi sosial, kelas sosial, dan status sosial yang memberikan pengaruh lalu berkembang menjadi hambatan terhadap peran baru yang tengah mereka jalankan, yaitu peran sebagai mahasiswa. Dalam kehidupan, peran yang telah disusun oleh masyarakat mengatur apa dan bagaimana peran setiap orang dalam pergaulan. Jika ingin kehidupan sosial tetap harmonis, maka harus mematuhi persyaratan peran. Jadi, orang biasanya melakukan apa yang sesuai dengan peran mereka. Oleh karena itu, gambaran konflik peran tidak dapat dilihat hanya di satu sisi, tetapi ada pengaruh timbal balik antara aktor dan struktur sosial. Oleh karena itu, untuk mengatasi konflik peran tersebut diperlukan solusi untuk memainkan peranan itu secara baik. Solusi ini dijembatani oleh bentuk interaksi sosial Minangkabau dengan mempraktekkan 
kaba baiak baimbauan, kaba buruak bahambauan. Cara kerja ini menciptakan role making di tengah-tengah kesibukan mereka, dengan melibatkan orang-orang terdekat untuk mewakili dan membantu peran yang tidak bisa mereka laksanakan di tengah-tengah lingkungan masyarakat tanpa mengurangi nilai mereka dimata orang lain. Dengan demikian role making mendudukkan individu sebagai pihak yang aktif dalam menetapkan perilakunya dan membangun harapan-harapan sosial.

\section{E. UCAPAN TERIMA KASIH}

capan terimakasih saya sampaikan kepada pihak-pihak yang telah membantu kelancaran dalam penelitian ini, khususnya pimpinan dan para staf di Stikes Syedza Saintika Padang beserta seluruh informan yang telah menyediakan waktunya untuk memberikan bantuan dan informasi sehingga penelitian ini dapat selesai.

\section{DAFTAR PUSTAKA}

Amir, M. (2011). Adat Minangkabau Pola dan Tujuan Hidup Orang Minang. Jakarta: Citra Harta Prima.

Arifin, Zainal. (2013). Bundo Kanduang: (hanya) Pemimpin di Rumah (Gadang). Jurnal Antropologi Indonesia, Vol.34 No.2, pp. 124-133. Doi:https://doi/org/10.7454/ai.v34i2.3968

Arifin, Zainal. (2009). Dualitas Praktik Perkawinan Minangkabau. Jurnal Humaniora, Volume 21, No.2, p.151. doi: https://doi.org/10.22146/jh.963.

Aryati, D., Prastiwi, S., \& Rosdiana, Y. (2017). Motivasi Belajar Mahasiswa yang Sudah Berkeluarga dengan Indeks Prestasi (IP) di Fakultas Kesehatan Universitas Tribhuana Tunggadewi Malang. Nursing News, Volume 2, Nomor 3, pp. 251-259.

Ermawati, S. (2016). Peran Ganda Wanita Karier (Konflik Peran Ganda Wanita Karier Ditinjau dalam Perspektif Islam). Jurnal Edutama, Vol. 2, No. 2, pp. 59-69 doi: http://dx.doi.org/10.30734/jpe.v2i2.24

Henslin, J. M. (2006). Sosiologi dengan Pendekatan Membumi. Jakarta: Erlangga.

Idi, A. (2011). Sosiologi Pendidikan: Individu, Masyarakat, dan Pendidikan. Jakarta: Rajawali Press.

Jones, P. (2009). Pengantar Teori-teori Sosial . Jakarta: Yayasan Pustaka Obor Indonesia.

Maliki, Z. (2010). Sosiologi Pendidikan. Yogyakarta: Gadjah Mada University Press.

Martono, N. (2012). Sosiologi Perubahan Sosial: Perspektif Klasik, Modern, Postmodern, dan Poskolonial. Jakarta: PT RajaGrafindo Persada.

Meliza, R., Iskandar, B. S., \& Soemarwoto, R. S. (2019). Aspek Ekonomi Pada Kehidupan Perempuan Lanjut Usia: Studi Etnografi di desa Demuk, Kecamatan Pucanglaban, Kabupaten Tulungagung. Jurnal Antropologi: Isu-Isu Sosial Budaya-vol.21.No.01 , 11-21. doi:https://doi.org/10.25077/jantro.v21.n1.p11-21.2019

Saputri, E. Y. (2016). Peran Wanita Sebagai Kepala Keluarga dalam Melaksanakan Fungsi Keluarga di Kelurahan Sungai Merdeka Kecamatan Samboja. eJournal Sosiatri-Sosiologi , Volume 4, Nomor 2, pp. 212-226.

Shonhaji. (2017). Keterlibatan Perempuan dalam Mewujudkan Keserasian Sosial Pada Masyarakat Multietnik di Lampung. Jurnal TAPIs, Vol. 14, No. 01,18-44. doi:https://doi.org/10.24042/tps.v13i1.1397

Susanti, S., \& Ekayati, I. N. (2013). Peran Pekerjaan, Peran Keluarga, dan Konflik Pekerjaan Pada Perawat Wanita. Persona, Jurnal Psikologi Indonesia, Vol. 2, No. 2, pp. 183-190. Doi: https://doi.org/10.30996/persona.v2i2.118

Tatang, S. (2012). Ilmu Pendidikan. Bandung: Pustaka Setia. 